\title{
Informatics Open Library: Innovation in Developing Electronic- Service Case Study Departemen Informatics ITS
}

\section{Informatic Open Library: Inovasi \\ Pengembangan Layanan E-Service Studi Kasus Departemen Informatika ITS}

Eva Mursidah, Astutik Nur Qomariyah, Radityo Anggoro

Paper Type:

Research Paper

\section{Institut Teknologi Sepuluh Nopember Surabaya}

Abstract

Background of the study: Many of information resources available in the central library and Departemen Informatics of ITS, in various formats, printed, nonprinted, electronic collections, and other media that require users to search for independent information, so users are faced with various search and location options.

Purpose: This study aims to identify the problem of ability of library user to find the needs of information resources and Designing an integrated library information system in the Informatic Open Library application to solve user problems to find the needs of information resources.

Method: This research uses qualitative approach with descriptive methods.

Findings: Application development related to services and data security must continue to be done as well as analysis should be done every year by comparison with the analysis of the previous year to improve service quality at the highest level.

Conclusion: Based on the results of research in the field, the implementation of the Informatic Open Library has been good, the aim of facilitating services for Siva ITS Department of Information has been achieved and provides benefits for lecturers. Librarian, education staff, students, and institutions. The role of librarians and librarian collaboration with lecturers and students is a supporting factor in the successful implementation of the Informatic Open Library application.

Keywords: Integrated Library Information Systems, Informatic Open Library, Departemen of Informatic ITS Library.
Submitted: 25 February 2020 Online: 11 October 2020

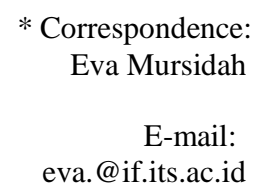




\section{Abstrak}

Latar belakang: Di kampus ITS banyak sekali sumber informasi yang tersedia, baik di perpustakaan pusat maupun Departemen Informatika yang tersedia dalam berbagai format, seperti; cetak, noncetak, koleksi elektronik, dan media lain yang mengharuskan pengguna mencari informasi secara mandiri, sehingga pengguna dihadapkan dengan berbagai pilihan pencarian dan lokasi.

Tujuan: Penelitian ini bertujuan untuk mengidentifikasi permasalahan kemampuan pengguna perpustakaan dalam memenuhi kebutuhan sumber informasi dan merancang sistem informasi perpustakaan terintegrasi pada aplikasi Informatic Open Library untuk menyelesaikan permasalahan pengguna dalam memenuhi kebutuhan sumber daya informasi.

Metode: Penelitian ini menggunakan pendekatan kualitatif dengan sifat deskriptif.

Temuan: Aplikasi Informatics Open Library ini tergolong baru, sehingga pengembangan untuk keberlanjutan sistem ke depan sangat diperlukan, namun perlu adanya pembanding antara analisis sebelumnya untuk mencapai peningkatan kualitas layanan pada level tertinggi.

Kesimpulan: Berdasarkan hasil penelitian di lapangan, implementasi Informatic Open Library sudah baik, tujuan mempermudah layanan bagi sivitas akademika Departemen Informatika ITS sudah tercapai dan memberikan manfaat bagi dosen. Pustakawan, tenaga pendidik, mahasiswa, dan institusi. Peranan pustakawan dan kolaborasi pustakawan dengan dosen dan mahasiswa merupakan faktor pendukung dalam keberhasilan implementasi aplikasi Informatic Open Library tersebut.

\section{Kata Kunci: Integrasi System, Informatic Open Library, Perpustakaan Departemen Informatika ITS.}

To cite this document:

Mursidah, E., Qomariyah, A. N., \& Anggoro, R. (2020). Informatic Open Library: Innovation in Developing Electronic- Service Case Study Departemen Informatics ITS. Record and Library Journal, 6(2), 166-174. Open access under Creative Commons Attribution-Non Commercial-Share A like 4.0 International Licence 


\section{Pendahuluan}

Kementerian Riset Teknologi dan Pendidikan Tinggi (Kemenristek Dikti) Indonesia memberi target Institut Teknologi Sepuluh Nopember (ITS) pada tahun 2023 untuk masuk ke jajaran universitas kelas dunia atau World Class University (WCU). Oleh karena itu, ITS mengadakan akselerasi terus menerus hingga kini untuk menuju WCU. Dalam rangka memperoleh pengakuan internasional tersebut, maka kualitas suatu perguruan tinggi adalah parameter utama, di mana kualitas penelitian (research quality) dan kualitas pengajaran (teaching quality) menjadi kekuatan dan ukuran utama perkembangan suatu perguruan tinggi.

Menjawab tantangan dalam peningkatan research quality dan teaching quality tersebut, maka harus didukung oleh perpustakaan yang memiliki peran signifikan untuk mencapai research dan teaching yang berkualitas. Salah satu yang dapat dilakukan perpustakaan adalah menyediakan kebutuhan sumber daya informasi (information resources) bagi sivitas akademikanya. Hal ini juga sesuai dengan Peraturan Pemerintah Republik Indonesia Nomor 24.

Pelaksanaan Undang-undang Nomor 43 Tahun 2007, tentang Perpustakaan, pasal 1 angka 10, menerangkan bahwa, "yang dimaksud dengan perpustakaan perguruan tinggi adalah perpustakaan yang merupakan bagian integral dari kegiatan pendidikan, penelitian, pengabdian kepada masyarakat, dan berfungsi sebagai pusat sumber belajar untuk mendukung tercapainya tujuan pendidikan yang berkedudukan di perguruan tinggi." Seperti diketahui, selain memiliki perpustakaan pusat, ITS juga memiliki perpustakaan sendiri-sendiri di masing- masing departemen, sesuai dengan kajian ilmu dari departemen yang bersangkutan, termasuk Perpustakaan Departemen Informatika.

Kini, sumber daya informasi yang tersedia di perpustakaan pusat maupun perpustakaan di masingmasing departemen terdiri dari berbagai format, seperti; printed, nonprinted, dan electronic, collections, dan media-media lainnya, sebagaimana yang terlihat pada Tabel 1. Kenyataan demikian juga diungkapkan oleh Anthony S. Chow dan Timothy Bucknall (2012), bahwa paradigma perpustakaan saat ini telah membagi sumber daya informasi menjadi berbagai "silo" yang berbeda-beda dan setiap informasi harus dicari secara mandiri oleh pengguna. Jika seseorang menginginkan buku tercetak yang dimiliki perpustakaan, mereka harus menemukan katalog perpustakaan (Online Public Access Catalog/OPAC). Jika mereka menginginkan artikel, mereka harus mencari database artikel. Jika mereka menginginkan e-book yang lebih lama, mereka harus mencari Google Book. Pustakawan dapat menguasai informasi yang kompleks dan bercabang-cabang, namun, tidak bagi pengguna perpustakaan. Saat pengguna dihadapkan dengan berbagai opsi pencarian dan lokasi, respon yang tidak berubah adalah, "Mengapa ini tidak bisa menjadi kotak pencarian tunggal, seperti Google?"

Tabel 1. Sumber Daya Informasi Perpustakaan Informatika ITS Tahun 2019

\begin{tabular}{llllll}
\hline No & Jenis koleksi & Tercetak & \multicolumn{3}{c}{ Elektronik } \\
\cline { 3 - 6 } & Judul & Eks & Judul & Eks \\
1 & Buku teks & 2210 & 3303 & 205 & 205 \\
2 & Jurnal/Majalah & 76 & 235 & - & - \\
3 & Buku referensi & 15 & 15 & - & - \\
4 & Laporan Kerja Praktek & 1307 & 1307 & 1307 & 1307 \\
5 & Skripsi & 3162 & 3162 & 1502 & 1502 \\
6 & Tesis & 676 & 676 & 345 & 345 \\
7 & Disertasi & 10 & 10 & 110 & 10
\end{tabular}

Sumber: data diolah

Maka dari itu, di sinilah fungsi pustakawan untuk bisa membimbing dan membantu pemustaka dalam menemukan sumber informasi yang tepat untuk nantinya digunakan, di mana kontennya telah terseleksi sesuai subjek dan bidang ilmu, tentunya akan mempermudah pemustaka dalam proses temu kembali informasi dan koleksi yang dibutuhkan. Berdasarkan latar belakang tersebut, inovasi baru akan dilahirkan oleh Perpustakaan Departemen Informatika, yakni sistem yang dibangun dalam sebuah 
aplikasi yang disebut Informatic Open Library yang fungsinya adalah menyimpan pengetahuan dan dapat dimanfaatkan oleh pengguna dalam memenuhi kebutuhan informasinya, di mana aplikasi Informatic Open Library merupakan implementasi dari sistem informasi perpustakaan terintegrasi (Integrated Library Information Systems).

Informatic Open Library dihadirkan sebagai representasi layanan E-Services untuk mengakomodasi sivitas akademika yang telah terlahir pada era digital, di mana rata-rata telah menguasai teknologi informasi dan strategi penelusuran dasar. Jumlah sivitas akademika millenial di ITS berjumlah sangat besar, sehingga keberadaan pustakawan saat ini agaknya masih kurang mencukupi. Dengan adanya aplikasi Informatic Open Library, maka dapat memudahkan sivitas akademika ITS untuk memperoleh sumber informasi dan koleksi yang dibutuhkan. Penggunaan aplikasi Informatic Open Library juga tidak bergantung pada jam buka perpustakaan karena mahasiswa dapat menggunakannya 24 jam selama akses terhadap Informatic Open Library masih dibuka. Informatic Open Library nantinya juga akan mempercepat siklus transfer informasi sehingga pengetahuan baru akan banyak tercipta dari manusia yang mengolah pengetahuan dan informasi yang telah didapat.

\section{Metode Penelitian}

Penelitian ini menggunakan pendekatan kualitatif dengan sifat deskriptif. Sebagaimana Idrus (2009), menjelaskan bahwa penelitian kualitatif dengan sifat deskritif adalah mengenai situasi atau proses yang diteliti. Sesuai dengan definisi tersebut penelitian ini di lakukan untuk menggambarkan inovasi pelayanan elektronik service.

Dalam penelitian ini, lokasi yang digunakan dalam unit analisis studi kasus adalah Perpustakaan Departemen Informatika ITS, dengan memfokuskan pada implementasi aplikasi Informatics Open Library sebagai perwujudan layanan e-services dilihat dari:

1. Informatics Open Library: Implementasi Integrated Library Systems (ILS)

2. Pelaksanaan dan peranan pustakawan dalam implemetasi sistem

3. Perbandingan jenis layanan sebelum dan sesudah terintegrasi

4. Capaian aplikasi Informatic Open Library

Analisis data menggunakan model analysis interactive dari Miles dan Huberman (1994) yang membagi kegiatan analisis menjadi beberapa bagian yaitu: pengumpulan data, reduksi data, penyajian data, dan penarikan kesimpulan atau verifikasi data.

\section{Hasil dan Diskusi}

\section{Informatics Open Library: Implementasi Integrated Library Systems ( ILS)}

Perpustakaan Departemen Informatika mengikuti perkembangan dan mengadopsi teknologi informasi dalam rangka mencapai tujuannya. Layanan baru secara bertahap mengganti layanan lama, di mana Perpustakaan Departemen Informatika harus dinamis dan berorientasi pada masa depan. Hal ini, juga untuk menjawab tantangan yang dihadapi pustakawan, pengguna dan perpustakaan pada era digital, teknologi dalam masa transisi, dan keragaman jenis koleksi terutama koleksi elektronik. Inovasi dengan membangun sistem perpustakaan terintegrasi dengan satu pintu.

Konsep sistem perpustakaan terintegrasi yang diimplementasikan pada aplikasi Informatics Open Library merupakan pengembangan perpustakaan digital Departemen Informatika yang di manfaatkan sebagai layanan $e$-service oleh pengguna. Sistem itu dirancang untuk membantu perpustakaan dengan tiga tugas utama: 1. Meningkatkan efisiensi operasional; 2. Memberikan akses ke sumber daya informasi perpustakaan; 3. Menyediakan akses ke sumber daya informasi eksternal. Hal itu, sesuai dengan pendapat dari David (2001:12) yang menyatakan sistem perpustakaan terintegrasi merupakan istilah untuk menyebut ketika sistem manajemen perpustakaan menggunakan sharing database server untuk menjalankan semua fungsi pekerjaan perpustakaan. Sedangkan, Muller (2011:57) menyatakan bahwa sistem perpustakaan terintegrasi adalah aplikasi perangkat lunak multifungsi yang dapat beradaptasi untuk memungkinkan perpustakaan melakukan pengelolaan, pengkatalogan, dan sirkulasi sumber daya informasi perpustakaan ke pengguna mereka.

To cite this document:

Mursidah, E., Qomariyah, A. N., \& Anggoro, R. (2020). Informatic Open Library: Innovation in Developing

Electronic- Service Case Study Departemen Informatics ITS. Record and Library Journal, 6(2), 166-174.

Open access under Creative Commons Attribution-Non Commercial-Share A like 4.0 International Licence

(CC-BY-SA) 
Manfaat yang dirasakan dengan adanya aplikasi Informatic Open Library adalah; 1. Bagi pustakawan, membantu pekerjaan pustakawan lebih efektif dan efesien; 2. Bagi dosen, mendapatkan informasi terbaik dengan cara yang mudah dan dapat dilakukan secara mandiri di manapun dan kapanpun untuk kepentingan pengajaran dan penelitian; 3. Bagi mahasiswa, pemanfaatan aplikasi ini untuk keperluan tugas kuliah, tugas akhir, dan penelitian; 4. Bagi tenaga kependidikan, pemanfaatan aplikasi untuk keperluan penulisan karya ilmiah institusi; 5. Bagi institusi, alokasi dana untuk pengadaan sumber daya informasi dapat termanfaatkan dengan baik, sehingga secara otomatis mendorong jumlah publikasi ilmiah dan internasionalisasi ITS.

Dalam implementasinya layanan pada aplikasi Informatic Open Library dapat diakses secara mandiri kapanpun dan di manapun tanpa batas ruang dan waktu melalui perangkat komunikasi apapun sepanjang terdapat akses internet. Prinsip kemudahan dan mandiri menjadi hal utama dalam kesuksesan aplikasi. Untuk masuk pada aplikasi tanpa login dan pasword pada link http://Informatic Open Library.if.its.ac.id/public/ dan langsung masuk ke dalam dashboard. Tampilan pertama kali ketika membuka aplikasi Informatic Open Library memperlihatkan gambar learning space Perpustakaan Deaprtemen Informatika tidak ada menu yang aktif untuk user.

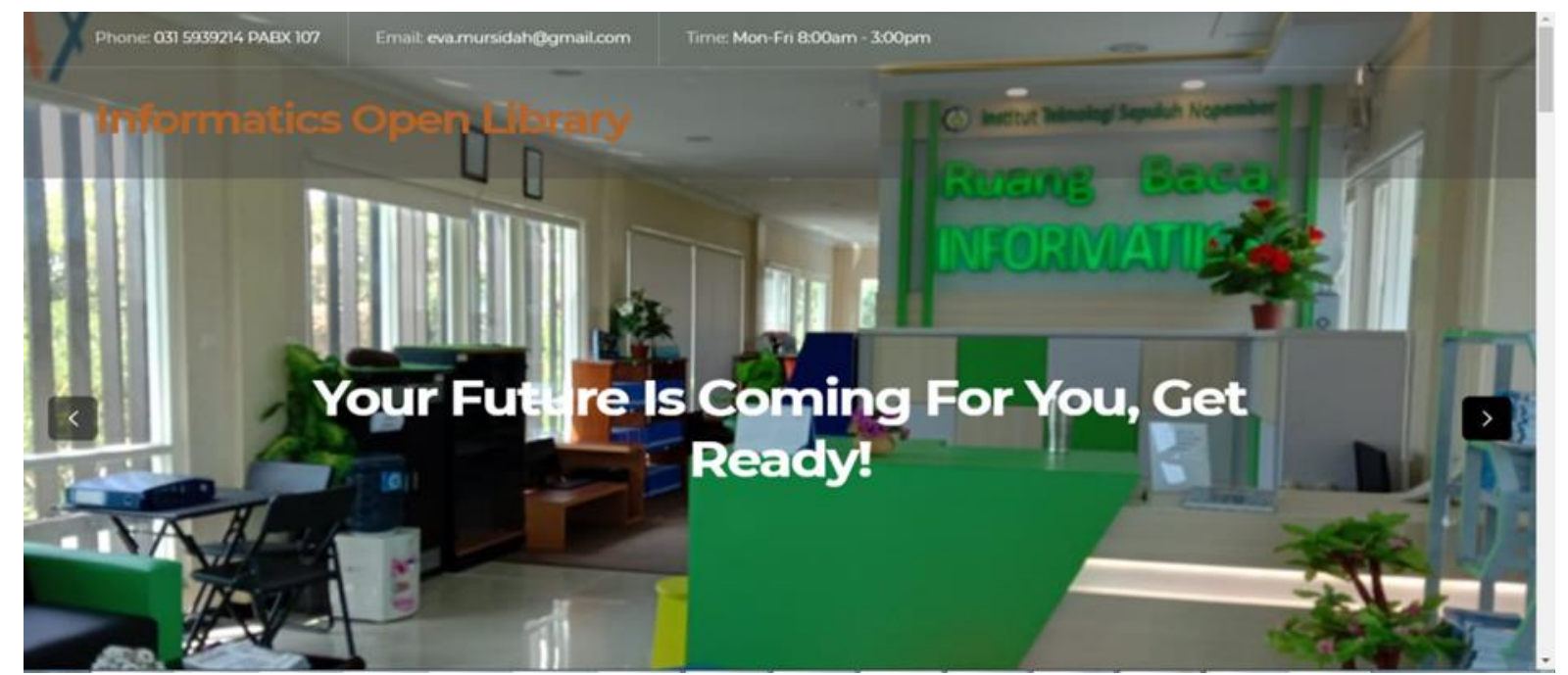

Gambar 1. Tampilan Awal Informatic Open Library

Gambar 2 di bawah ini, menjelaskan menu-menu pada aplikasi Informatic Open Library: 1. Menu our service yang terigentrasi dengan layanan inti Perpustakaan Departemen Informatika, menu tersebut adalah layanan referensi vitual, layanan literasi informasi, layanan bebas pustaka, dan unggah mandiri, layanan cek plagiarism, layanan pengadaan buku baru, layanan survei pengguna, sirkulasi mandiri, panduan VPN, dan panduan penggunaan aplikasi Informatic Open Library dalam format pdf yang bisa di download; 2. Menu konten lokal yang dimiliki Perpustakaan Departemen Informatika, menu tersebut adalah katalog online, JUTI, dan repositori Departemen Informatika; 3. Menu electronic resources yang terdiri dari menu yang mengarah ke link database jurnal ACM Digital Library yang dilanggan Departemen Informatika, institusional repository perpustakaan ITS, database e-jurnal, dan e-book yang di langgan Perpustakaan ITS, e-resources Perpustakaan Nasional, perpustakaan digital Perpustakaan Kemenristek DIKTI, Scopus dan Sinta; 4. Menu open access yang terdiri dari fitur yang mengarah ke link IOS, DOAJ, portal garuda atau sinta, serta SIM LIBTAMAS dari Dirjen DIKTI.

To cite this document:

Mursidah, E., Qomariyah, A. N., \& Anggoro, R. (2020). Informatic Open Library: Innovation in Developing Electronic- Service Case Study Departemen Informatics ITS. Record and Library Journal, 6(2), 166-174. Open access under Creative Commons Attribution-Non Commercial-Share A like 4.0 International Licence 


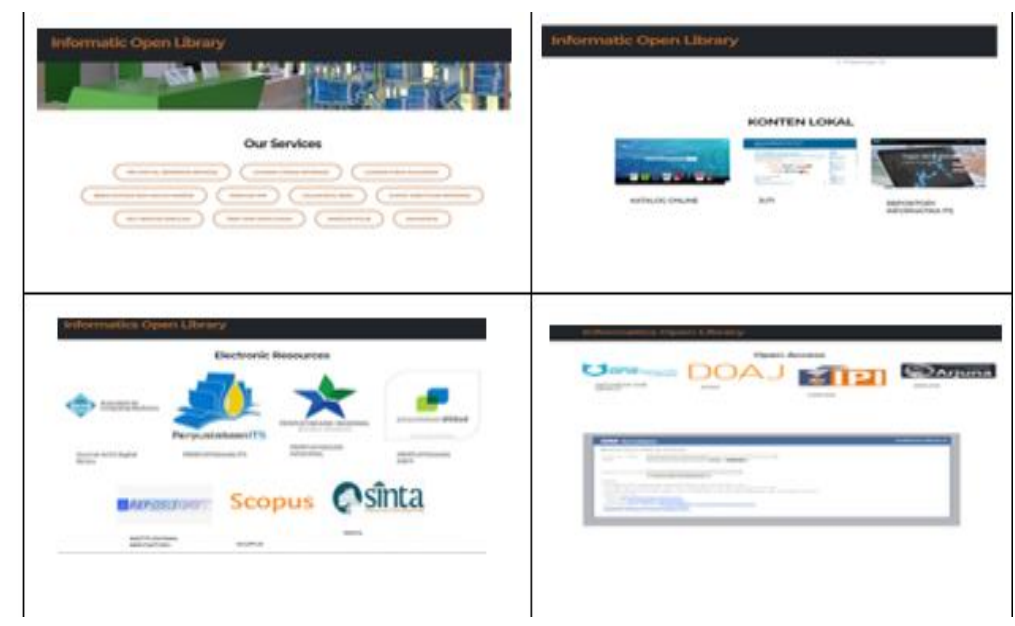

Gambar 2. Tampilan Menu-Menu Informatic Open Library

\section{Pelaksanaan dan Peranan Pustakawan dalam Implementasi Sistem}

Pengembangan prototype aplikasi Informatic Open Library merupakan kolaborasi antara pustakawan dan dosen, mahasiswa dan teknisi laboratorium manajemen sistem informasi Departemen Informatika yang ahli dalam computer programming dan analyst system. Hal ini, sesuai dengan pernyataan Koswara (2008,h.50-53) mengungkapkan bahwa, sumber daya manusia meliputi system analyst yang mempunyai keahlian dalam menganalisis sistem, diperlukan kalau akan membuat sistem informasi yang baru, sebelumnya harus dianalisis sistem yang sedang berjalan, lalu ditentukan perbaikan apa yang harus dilakukan, programmer yang mempunyai keahlian membuat dan mengembangkan program komputer terutama yang berbasis OSS, sehingga akan dengan mudah dan cepat dalam membuat perangkat lunak yang diperlukan.

Kegiatan perancangan sistem di awali dengan penyebaran kuesioner secara online pada dosen dan mahasiswa pengguna perpustakaan sebanyak 86 responden. Aspek-aspek dalam survei terkait dengan kebutuhan informasi pengguna perpustakaan yaitu: 1. Karakteristik informasi; 2. Sumber daya informasi; 3. Penggunaan informasi; dan 4. Kinerja pustakawan. Hasil survei yang diperoleh dari aspek karakteristik informasi dan sumber daya informasi berfungsi untuk proses pengelompokan modul dan fitur berdasarkan grup menu.

Pustakawan sebagai salah satu aspek sumber daya manusia memiliki peran yang besar dalam upaya menyeleksi dan menganalisis konten atau informasi yang akan disimpan dalam aplikasi Informatic Open Library tersebut dengan melakukan kemas ulang infomasi. Pustakawan mengelompokkan sumber daya informasi elektronik berdasarkan jenis, subjek, dan bidang ilmu tertentu. Fungsinya tak lain adalah membantu pengguna dalam upaya temu kembali informasi saat melakukan penelusuran pada aplikasi Informatic Open Library.

Sementara peranan pustakawan dalam pengembangan sistem antara lain; 1. Perencanaan: ide pembuatan; 2. Kebutuhan Sistem: melakukan survei kebutuhan informasi yang di gunakan sebagai elemen kebutuhan sistem; 3. Implementasi: Melakukan pemetaan setiap sumber daya informasi sesuai dengan fungsi; 4. Sosialisasi: Sosialisasi dilakukan ke dosen dan mahasiswa melalui kegaitanan IPTS dan OK2BK, Sharing ke dosen melalui berita informatika, ke perpustakaan pusat; 5. Evaluasi dilakukan dengan mencari titik titik lemah dari setiap aplikasi dan selanjutnya terus dikembangan, Aplikasi Informatic Open Library saat ini juga masih dalam tahap pengembangan berkelanjutan untuk dapat digunakan, tidak hanya oleh sivitas akademika yang terdapat di Departemen Informatika, namun juga berkontribusi terhadap kemajuan dan peningkatan kualitas pengajaran dan kualitas penelitian di ITS.

\section{Perbandingan Penerapan Layanan Perpustakaan Sebelum dan Sesudah Terintegrasi}

Berikut adalah pernbandingan sebelum dan sesudah layanan Perpustakaan IF terintegrasi dapat dilihat dibawah ini:

To cite this document:

Mursidah, E., Qomariyah, A. N., \& Anggoro, R. (2020). Informatic Open Library: Innovation in Developing

Electronic- Service Case Study Departemen Informatics ITS. Record and Library Journal, 6(2), 166-174.

Open access under Creative Commons Attribution-Non Commercial-Share A like 4.0 International Licence

(CC-BY-SA) 
Tabel 2. Perbandingan Sebelum dan Sesudah Terintegrasi

\begin{tabular}{l}
\hline Layanan \\
\hline Layanan \\
Rujukan \\
Informasi \\
\\
Layanan Literasi \\
Informasi \\
\\
Layanan \\
Bebas Puistaka \& \\
Unggah Mandiri
\end{tabular}

Sebelum
Menggunakan teknologi
komunikasi seperti email,
whatsup secara pribadi ke
pustakawan, banyaknya spam
terkadang pengiriman informasi
terlambat.

Sesudah
Menggunkan web form
sehingga pengiriman informasi
lebih termonitoring

Modul/Url

http://Informatic

Open Library.if.i

ts.ac.id/public/l

$\underline{\text { ss/lss.html }}$

terlambat.

Pengguna harus melakukan kunjungn fisik secara langsung ke tempat diadakannya kelas literasi (Training Literasi Informasi )

Menggunakan web e-resource class online dalam bentutuk

http://eresource tutorial online dan pengajaran dalam bentuk video

-mi.com/

Layanan on site tergantung jam buka layanan perpustakaan sehingga terjadi antrian panjang untuk melakukan bebas pustaka sebagai syarat yudisium karena banyak persyaratan

Layanan

Tren Topik

Untuk melakukan pengembangan topik karya ilmiah bertanya secara langsung ke pembimbing, pustakawan atau mencatat dari sistem informasi perpustakaan

Menggunakan online dalam http://yudisium bentuk aplikasi yudisium untuk $\underline{\text { if.its.ac.id }}$ upload persyaratan bebas pustaka dan dapat dilakukan di manapun dan kapanpun

Menggunakan aplikasi tren topik untuk mendapatkan informasi karya ilmiah yang akan dikembangkan, aplikasi ini sekaligus di gunakan untuk rekomendasi pengadaan bahan pustaka

\section{Layanan \\ Sirkulasi \\ Sirkulasi bahan pustaka melalui Pustakawan}

\author{
Layanan Cek \\ Plagiasi \\ Layanan
Usulan Buku
Baru
}

\section{Layanan \\ Karya Ilmiah}

Belum ada

Usulan pengadaan buku baru dengan menggunkan form usulan secara manual atau menginformasikan langsung ke dosen dan mahasiwa akibatnya proses pengadaan lebih lama

Untuk mendapatkan informasi karya ilmiah harus datang secara langsung ke perpus atau mendapatkan file pdf melalui repositori
Sirkulasi bahan pustaka dapat dilakukan secara mandiri dengan menggunakan aplikasi self service sirkulasi

Cek plagiasi dengan menggunakan software plagiasi

https://www.gr ammarly.com/

Usulan buku menggunakan aplikasi usulan pengadaan buku dengan menggunakan web form sehingga lebih termonitoring dan proses lebih cepat

Selain buku dan soft file dalam bentuk PDF dapat juga memperoleh informasi melalui video dan poster karya ilmiah melalui web mahakarya
http://Informatic Open Library.if.i ts.ac.id/public/l ss/request.html

http://mahakar ya.if.its.ac.id/

To cite this document:

Mursidah, E., Qomariyah, A. N., \& Anggoro, R. (2020). Informatic Open Library: Innovation in Developing Electronic- Service Case Study Departemen Informatics ITS. Record and Library Journal, 6(2), 166-174. Open access under Creative Commons Attribution-Non Commercial-Share A like 4.0 International Licence 


\begin{tabular}{ll}
\hline Layanan & Survei kepuasan pengguna \\
Keluhan dan & maupun keluhan terhadap \\
Survei & $\begin{array}{l}\text { layanan dilakukan secara } \\
\text { konvensional }\end{array}$
\end{tabular}

Layanan

Keluhan dan
Survei kepuasan pengguna

terhadap layanan dilakukan secara online melalui aplikasi online google form

\section{https://docs.go \\ ogle.com/form \\ s/d/1GbnZb3X \\ Pj4F9CzZKhH \\ UEkgpt5DRT \\ ZSX31OCNkI}

4c-8/edit

\section{Capaian Aplikasi Informatic Open Library}

Berdasarkan statistik pengunjung aplikasi Informatic Open Library sejak peluncurannya pada akhir pertengahan Juli 2019, aplikasi ini telah digunakan oleh mahasiswa, dosen, dan staf Departemen Informatika. Data yang digunakan pada penelitian ini adalah statistik pertengahan bulan Juli sampai Agustus 2019, beberapa hari sejak peluncuran Informatic Open Library pada 16 Juli 2019. Bulan Juli merupakan masa perkuliahan libur semester, akan tetapi banyak mahasiswa yang melakukan kunjungan untuk mengurus bebas pustaka, sehingga memanfaatkan layanan bebas pustaka dan unggah mandiri. Perkuliahan dimulai kembali pada akhir bulan Agustus 2019.

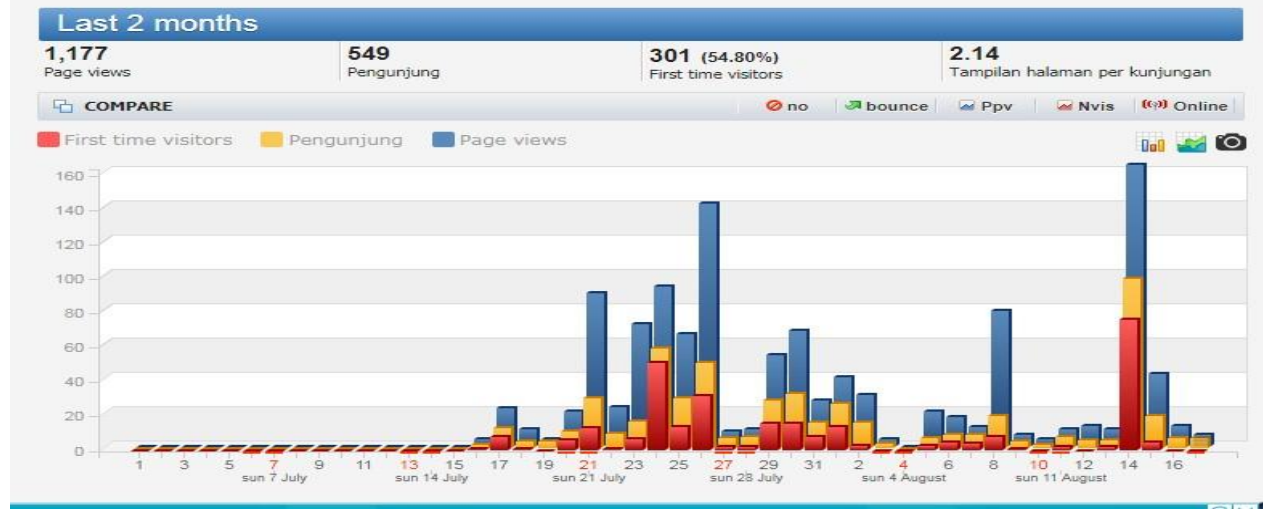

Gambar 3. Staistik Pengunjung Informatic Open Library diakses Tgl 16 Agustus 2019

Setiap hari, setidaknya lebih dari 18 kunjungan ke Informatic Open Library selama hampir satu bulan ini. Menandakan pemustaka cukup antusias terhadap layanan $e$-service ini.

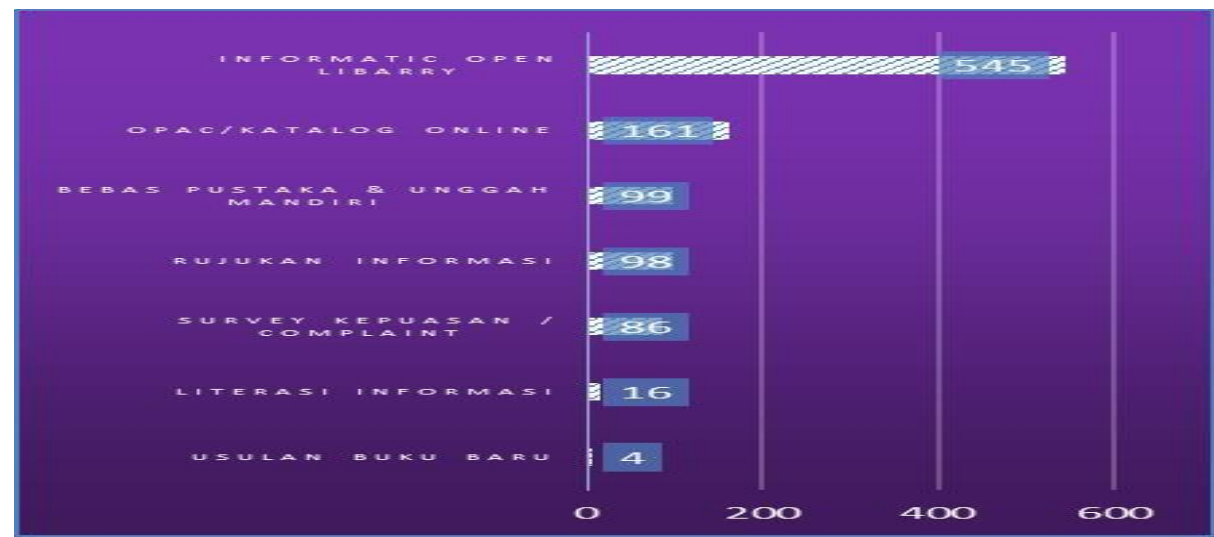

Gambar 4: Top 10 Statistik Kunjungan ke Informatic Open Library

Gambar 4 di atas, menjelaskan jumlah top 10 kunjungan ke website adalah kunjungan ke home page pada aplikasi Informatic Open Library, dalam satu bulan pemanfaatan ke home page Informatic Open Library paling tinggi sebesar 545, sebanyak 161 pengunjung yang memanfaatkan layanan katalog online

To cite this document:

Mursidah, E., Qomariyah, A. N., \& Anggoro, R. (2020). Informatic Open Library: Innovation in Developing Electronic- Service Case Study Departemen Informatics ITS. Record and Library Journal, 6(2), 166-174.

Open access under Creative Commons Attribution-Non Commercial-Share A like 4.0 International Licence 
melalui web slim akasia 8,9 pengunjung yang memanfaatkan web survey kepuasan, web yudisium, dan web LSS, kepuasan dengan akses aplikasi oline survey kepuasan; 2 pengunjung memanfaatkan web eresources class, dan 1 pengunjung memanfaatkan web usulan pengadaan koleksi bahan pustaka. Sementara layanan cek plagiarism masih belum mendapatkan angka di karenakan layanan ini tergolong baru di Perpustakaan IF.

\section{Simpulan}

Berdasarkan hasil penelitian di lapangan, implementasi Informatic Open Library sudah cukup baik, tujuannya untuk mempermudah layanan bagi sivitas akademika Departemen Informatika ITS sudah tercapai dan memberikan manfaat bagi dosen. pustakawan, tenaga pendidik, mahasiswa, dan institusi. Peranan pustakawan dan kolaborasi pustakawan dengan dosen dan mahasiswa merupakan faktor pendukung dalam keberhasilan implementasi aplikasi Informatic Open Library tersebut.

Mengingat aplikasi Informatics Open Library ini tergolong baru, maka pengembangan untuk keberlanjutan sistem kedepan sangat diperlukan, namun sebelumnya analisis harus dilakukan juga dengan cara membandingkan dengan analisis sebelumnya, sampai peningkatan kualitas layanan pada level tertinggi.

\section{Referensi}

Anthony S. Chow dan Timothy Bucknall (2012). Library Technology and User Services: Planning,Integration, and Usability Engineering. Oxford UK: Chandos Pub.

Arjayay. (2018). Management System - Wikipedia," Wikipedia Foundation, 25 November 2017. [Online]. Available: https://en.wikipedia.org/wiki/Management_system. [Accessed 5 April 2019].

David, L. T. (2001). ICT for library and Information Professionals : A Training package for developing countries. Module 2 Introduction to Integrated Library Systems. Bangkok:Unesco. unesdoc.unesco.org/images/0012/001251/125105e.pdf, akses 11 Desember 2006 pk 8:46 am

Navastara, D. (2018). Clustering Tren Topin Penelitian untuk Pengadaan Bahan Pustaka. Retrieved from https://riset.its.ac.id/klaster- topik/public

Evans, G. E. and Saponaro, M. Z. (2005). Library and Information Center. London: Libraries Unlimited Idrus, M. (2009). Metode Ilmu Penelitian Sosial . Yohyakarta : Erlamngga.

Indonesia. (2007). Undang-undang Republik Indonesia tentang Perpustakaan. Cet. III.Perpustakaan Rasional RI: Jakarta.

Kiondo, E. (2004). Around the World to: The University of Dar es Salaam Library:Collection Development in the Electronic Environment. Library Hi Tech News, (21/6). 19.

Koswara, E. (2008). E-Government Berbasis Open Source. Jemberana Networking Miles, M. B. dan Hubberman, A. M. (1992). Analisis Data Kualitatif. Jakarta: UI Press.

Müller, T. (2011). How to choose an free and open source integrated library system. OCLC Systems \& Services: International digital library perspectives, 27(1), 57-78. Retrieved March 12, 2011 from http://eprints.rclis.org/bitstream/10760/15387/1/How to choose an open source ILS.pdf

Munif, A. (2018). Website Edukasi E-Resources Perpustakaan ITS sebagai Media Literasi Informasi yang Efektif. Retrieved from http://eresource-mi.com/

Purnomo, A. (2018). Rancang Bangun Self Service Sirkulasi berbasis Software otomasi SLIMS Akasia 8. Retrieved from http://rbtc.if.its .ac.id/v8/login2/index.php

RBTC, "RBTC|Ruang Baca Jurusan Teknik Informatika - ITS (2018) . OPAC," Retrieved Juli 12, 2019 from http://rbtc.if.its.ac.id/v8/

RBTC, "RBTC | Ruang Baca Jurusan Teknik Informatika - ITS (2019). Informatic Open Library," Retrieved Juli 12, 2019 from http://Informatic Open Library.if.its.ac.id/public

To cite this document:

Mursidah, E., Qomariyah, A. N., \& Anggoro, R. (2020). Informatic Open Library: Innovation in Developing

Electronic- Service Case Study Departemen Informatics ITS. Record and Library Journal, 6(2), 166-174.

Open access under Creative Commons Attribution-Non Commercial-Share A like 4.0 International Licence

(CC-BY-SA) 